\title{
Os deveres do erudito: filosofia e oratória em Fichte
}

\author{
The duties of the scholar: philosophy and oratory in Fichte
}

\author{
Ulisses Razzante Vaccari \\ ulisses_vaccari@hotmail.com \\ (Universidade Federal de Santa Catarina, Santa Catarina, Brasil)
}

\begin{abstract}
Resumo: 0 artigo procura investigar 0 papel da oratória na filosofia de Fichte, principalmente nas Preleções sobre o destino do erudito e em Sobre o espírito e a letra na filosofia. Para isso, procura mostrar, num primeiro momento, que a concepção de erudito [Gelehrter] de Fichte é devedora do conceito kantiano de gênio e ao mesmo tempo da concepção de Cícero segundo a qual é dever do erudito, na qualidade de educador, unir às suas qualidades filosóficas também as da oratória. Num segundo momento, o artigo refaz a distinção entre espírito e letra e procura mostrar como a oratória pode ser pensada como uma forma de despertar o espírito do ouvinte por meio de uma teoria da imaginação produtiva.
\end{abstract}

Palavras-chave: oratória; preleção; ação; espírito; letra.

\begin{abstract}
The aim of this paper is to investigate the role of the speech in the philosophy of Fichte, mainly in the Vorlesungenüber die Bestimmung des Gelehrten and in the Über Geist und Buchstabe in der Philosophie. For this, tries to show, at first, that Fichte's concept of scholar [Gelehrter] owes both the Kantian concept of genius and Cicero's conception according to which it is the duty of the scholar, as an educator, attach to his philosophical qualities also that of oratory. Secondly, the article retraces the distinction between spirit and letter and tries to show how public speaking can be thought of as a way to awaken the spirit of the listener through a theory of productive imagination.
\end{abstract}

Keywords: speech; lecture; action; spirit; letter.

DOI: http://dx.doi.org/10.11606/issn.2318-9800.v20i2p87-103

Eu próprio assim fiz para meu benefício, ao conjugar sempre as letras latinas com as gregas - e isto não só o realizei na filosofia mas também no exercício da oratória ${ }^{1}$.

A conversação também se sustenta muito bem com ele [Fichte] e, como nos promete reconciliar o senso comum com a filosofia, devemos prestar bastante atenção em sua produção ${ }^{2}$.

1 CíCERO, M. T. Dos deveres. Tradução de Carlos Humberto Gomes. Lisboa: Edições 70, 2000, p.15.

2 GOETHE, J. W. "Carta de 28 de junho de 1794". In: FICHTE, J. G. Fichte im Gespräch. Stuttgart - Bad Cannstatt: Friedrich Frommann Verlag (Günther Holzbog), 1981, vol. I, p.196. 
Escritas no verão de 1794, as preleções de Fichte sobre $O$ destino do erudito fornecem ao leitor uma visão um tanto diferente de sua filosofia em relação à conhecida versão da Doutrina-da-ciência de 1794, a chamada Grundlage. Enquanto esta última foi redigida como espécie de manual para os cursos específicos sobre a Doutrina da Ciência, ministrados na Universidade de lena naquele mesmo ano, as Preleções sobre o destino do erudito, visando não apenas os estudantes de filosofia, mas o público geral da universidade, trazem à tona a relação entre filosofia e oratória, aspecto ainda pouco estudado no interior do pensamento do filósofo. Inteiramente voltada para a ação, e ao mesmo tempo crítica do saber erudito no mau sentido da palavra, a filosofia de Fichte leva igualmente em conta, como uma etapa necessária de sua realização, o momento exortatório para a ação: "Agir! Agir! É para isso que estamos aqui"', lê-se ao final das preleções.Longe de constituir apenas um aspecto acessório de seu pensamento, a força oratória dos cursos públicos de Fichte surge aos olhos de um leitor mais atento como um elemento imprescindível de sua filosofia, responsável justamente por conectar uma ideia racional, em si mesma vaga, à sua possível realização no mundo sensível.

O caráter predominantemente oral da obra em questão salta aos olhos já no título: Algumas preleções sobre o destino do erudito [Einige Vorlesungen über die Bestimmung des Gelehrten]. 0 termo "preleções" indica de antemão que o texto não foi escrito para ser lido solitariamente, mas declamado ao público, tal como ocorreu no dia 23 de maio de 1794, dia da primeira palestra do filósofo naquela universidade, com o auditório repleto. Mais tarde, Fichte se veria, a contragosto, obrigado a imprimir as preleções em forma de livro, quando, diante das acusações de jacobinismo ${ }^{4}$, precisou enviar o texto a Goethe, pedindo-lhe que desempenhasse o papel de juiz no conflito ${ }^{5}$. Nessa ocasião, Fichte escreve um proêmio à obra em que salienta o caráter predominantemente oral daquela exposição, sua impressão podendo acarretar alterações no seu objetivo mais profundo:

Um motivo externo, que em nada pode contribuir nem para o correto ajuizamento nem para a correta compreensão destas páginas, o moveu a deixar que se imprimissem separadamente estas cinco primeiras preleções e, na verdade, exatamente como ele as apresentou, sem nelas alterar uma palavra. Que isso possa desculpá-lo por algum descuido na expressão. - Por causa dos seus demais trabalhos, ele não pôde desde o início dar a esses escritos aquele acabamento que lhes desejava. Auxilia-se a exposição oral pela declamação. Modificá-los para a impressão teria contrariado um

3 FICHTE, J. G. O Destino do Erudito. Tradução de Ricardo Barbosa. São Paulo: Editora Hedra, 2014, p.92.

4 Cf. Idem, pp.106-111, Posfácio do tradutor, parte II.

5 Fichte voltaria a pedir a Goethe que desempenhasse o papel de juiz na querela que teve com Schiller em torno da publicação do texto Sobre o espírito e a letra na filosofia, no verão de 1795 , portanto, um ano depois. Cf. a introdução a FICHTE, J. G. Sobre o espírito e a letra na filosofia Numa série de cartas. Tradução de Ulisses Razzante Vaccari. São Paulo: Humanitas/Imprensa Oficial do Estado de São Paulo, 2015. 
propósito secundário desta6.

Imprimir um texto originalmente destinado à declamação era o mesmo que dar importância a um aspecto apenas secundário: a leitura. 0 fundamental dessas preleções, para Fichte, residia justamente no fato de terem sido escritas visando à declamação, de modo que seu conteúdo dependia em larga medida da forma como eram declamadas. Embora afirme que suas preleções poderiam ser simplesmente lidas, Fichte não deixa de reconhecer, como ocorrerá na querela com Schiller um ano mais tarde acerca da exposição da filosofia, a rigidez conceitual de seus escritos. Essa rigidez, entretanto, pode ser diluída por meio da declamação do texto: "a aparente rigidez na estrutura de minhas sentenças”, escreve ele a Schiller, "deriva, na maior parte, do fato de que os leitores não são capazes de declamá-las. Ouça-me ler algumas sentenças minhas e sua rigidez, assim penso eu, desaparecerá"7.

Essa forma peculiar de ler seus textos declamando, com efeito, tornaria Fichte famoso na Alemanha. Em uma carta de Friedrich Schlegel a seu irmão August, o autor romântico fala sobre a "maravilhosa eloquência deste homem nas Preleções sobre o destino do erudito" 8 .Em outro documento amiúde lembrado a respeito, Hölderlin, que assistira a essas preleções ao lado de Schlegel e Wilhelm von Humboldt, menciona Fichte como um "titã de lena", referindo-se à energia com a qual o filósofo defendia, em suas preleções, as causas da humanidade. Como nota Ricardo Barbosa, a preocupação de Fichte com o efeito da leitura sobre seus ouvintes leva-o a assumir um estilo característico de escrita, dotado de uma pontuação peculiar, a qual obedece a uma necessidade antes retórica e declamatória do que propriamente sintática ${ }^{10}$. Evidentemente, essa necessidade oratória está intimamente ligada a motivações propriamente filosóficas. Na primeira preleção, o filósofo menciona o propósito de estabelecer "pontos de contato" com o público "inculto", isto é, relações de ideias capazes de despertar nele o interesse pela filosofia e pelas questões do espírito em geral. Enquanto os cursos específicos sobre a Doutrina da

6 FICHTE, J. G. O destino do erudito, 2014, pp.9-10.

7 Carta de 27 de junho de 1795. In: FICHTE, J. G. Sobre o espírito e a letra na filosofia, 2015, p.199. Essa peculiaridade do seu estilo, na verdade, já tinha vindo à tona numa carta anterior a Schiller em que Fichte pedia ao poeta para corrigir alguns erros causados pelo seu copista num texto que ele enviava anexo para ser publicado na revista As Horas. Ao final desta carta, Fichte fazia um pedido especial: "dentre outras coisas de estilo, peço que observe a pontuação, que para mim é importante" (Idem, p.171). No fundo, Fichte reclamava nesta carta do fato de Schiller, sem consultá-lo, ter corrigido a pontuação do primeiro texto enviado por ele para As Horas, o Sobre a vivificação e a elevação do puro interesse pela verdade.

8 FICHTE, J. G. Fichte im Gespräch, 1981, p.297.

9 A expressão atribuída a Hölderlin é mencionada por Hegel numa carta a Schelling de janeiro de 1795. As palavras de Hegel são: "Hölderlin me escreve às vezes de lena. Ele ouve Fichte e fala dele com entusiasmo como um titã que lutaria pela humanidade". In: HEGEL, G. W. F. Briefe von und an Hegel. HOFFMEISTER, J. (org.). Hamburg: Felix Meiner Verlag, 1952, p.18.

10 Cf. FICHTE, J. G. O Destino do Erudito, 2014, p.11, nota 5 do tradutor. 
Ciência - reunidos posteriormente na Grundlage - podiam prescindir desse recurso oratório, nas preleções públicas esses pontos de contato deveriam ser construídos, como afirma Fichte, sobre o sentimento do ouvinte ainda não iniciado nas ciências do espírito. Ao afirmar, nessa mesma primeira preleção, que seu objetivo consiste em demonstrar a "destinação do homem em si", esclarece Fichte:

Como veem, meus senhores, o que tenho a dizer sobre isso não pode ser inteiramente deduzido, nessa sessão de uma hora, a partir dos seus fundamentos, a menos que quisesse tratar em uma hora da filosofia inteira. Mas posso construí-lo sobre o sentimento dos senhores ${ }^{11}$.

As preleçães, nesse sentido, estão em sintonia com o texto programático 0 conceito da Doutrina-da-ciência, escrito nesse mesmo ano, no qual Fichte trata igualmente da passagem da vida para a filosofia, ou do início do filosofar. Já perto de seu final, o texto aborda o problema do início da reflexão filosófica como um processo de cisão do eu em relação a si mesmo, condição necessária para o surgimento da autoconsciência. A dificuldade do princípio da filosofia reside no fato de essa separação ou "abstração reflexionante" não poder ser guiada por nenhuma coação cega, devendo ocorrer por liberdade, o que conduz necessariamente à questão: quais regras deve observar esse ato essencialmente livre? Nas palavras de Fichte: "como sabe o filósofo o que deve acolher como maneira-de-ação [Tathandlung] necessária da inteligência e o que deve deixar de lado como contingente?" "2. A resposta ilustra a obscuridade própria desse início: na passagem da vida para a filosofia, não há como saber o que se deve acolher como necessário e o que se deve deixar de lado como contingente. Pois, para saber como realizar a passagem, ela já deveria ter sido realizada, o que se contradiz. Ao que conclui Fichte:

o espírito humano faz toda sorte de tentativas; tateando cegamente chega até o alvorecer, e só depois passa para o dia claro. No princípio, é guiado por sentimentos obscuros (cuja origem e efetividade cabe à doutrina-da-ciência demonstrar); e até agora não teríamos nenhum conceito claro e seríamos sempre o torrão de terra que se extraviou do chão, se não tivéssemos principiado a sentir obscuramente aquilo que só mais tarde viemos a conhecer com clareza.

E acrescenta, numa nota:

Com isso fica claro que o filósofo deve ser dotado do sentimento obscuro do que é correto, ou de gênio, em grau não menor do que porventura o poeta ou o artista; só que de outro modo. Este último precisa do senso da beleza, aquele do da verdade; e tal senso certamente existe ${ }^{13}$.

11 Idem, p.18.

12 FICHTE, J. G. O conceito da doutrina-da-ciência. Tradução de Rubens Rodrigues Torres Filho. São Paulo: Abril Editorial, 1988, p.29.

13 Idem, ibidem. 
É sobre esse sentimento obscuro da verdade, presente em todo filósofo de início de carreira, que Fichte procura construir o argumento da destinação do homem em si, segundo o qual o eu empírico deve concordar com o eu puro e ideal. 0 objetivo, nas preleções, não é deduzir o fundamento desse sentimento a partir de princípios rigorosos, papel que caberá à Grundlage realizar e que aqui não poderá ser investigado ${ }^{14}$. Antes, o objetivo de Fichte nas preleções consiste em mostrar para os ouvintes que o sentimento ainda rudimentar e obscuro da verdade pode efetivamente conduzi-los a ela. Para isso, como se verá adiante, Fichte recorrerá à arte da oratória, dispondo as palavras de suas preleções de modo a despertar o sentimento ou o senso da verdade naquele que ainda não o possui e ao mesmo tempo certificar, para aquele que o possui mas ainda não está seguro dele, que ele está no caminho correto. Em outros termos, Fichte, nas preleções, esforça-se no sentido de dispor a letra de seu sistema de modo que, ao ser lida, ela ao mesmo tempo desperte e assegure o senso de verdade do ouvinte, sem coagi-lo.

A passagem do ouvinte "inculto" ao mundo do espírito realizada pelas preleções públicas de Fichte pressupõem uma influência do mundo suprassensível no mundo sensível, da liberdade no fenômeno, como se verá a seguir. Essa passagem, por isso, do mundo real ao ideal, da vida ao espírito, se torna possível por meio do estabelecimento dos referidos "pontos de contato" entre o "homem inferior e inculto" e o "homem superior e melhor". Afinal:

Se tudo se afigura como se o homem superior e melhor não tivesse nenhuma influência sobre o inferior e inculto, então nosso juízo em parte nos engana aqui, pois frequentemente esperamos pelo fruto antes que a semente possa germinar e desenvolver-se. Isto acontece em parte porque o melhor se encontra talvez a tantos níveis acima do inculto que ambos têm muito poucos pontos de contato entre si e podem agir muito pouco um sobre o outro ${ }^{15}$.

Nas preleções Sobre o espírito e a letra na filosofia - escritas um ano após as preleções Sobre o destino do erudito -, Fichte retornará àquela comparação do filósofo com o gênio artístico mencionado no Sobre o conceito da Doutrina-da-ciência: "sob a égide de sua capacidade divinatória, ele [o artista] deve estabelecer pontos de contato para toda a humanidade que não haviam sido até então comprovados em nenhuma experiência anterior" ${ }^{16}$.Do mesmo modo que o artista, ao nutrir-se, em seu métier, de uma relação necessária com a sensibilidade e assim estabelecer "pontos de contato" entre o mundo "inferior" e o "superior", também o filósofo ou o erudito

14 Cf. FICHTE, J. G. A doutrina-da-ciência de 1794. Tradução de Rubens Rodrigues Torres Filho. São Paulo: Abril Editorial, 1988, pp.156-62 (§§8-10). Sobre isso, cf. ROSALES, J. R. "Limite e realidade. Os primeiros passos no Sistema do idealismo transcendental". In: REY PUENTE, F. e Alves Vieira, L. (orgs.) As filosofias de Schelling. Belo Horizonte: Editora UFMG, 2005, pp.113-52.

15 FICHTE, J. G. O Destino do Erudito, 2014, p.41.

16 FICHTE, J. G. Sobre o espírito e a letra na filosofia, 2014, p.113. 
em geral o fazem na medida em que dispõem a palavra para ser declamada. Ao estabelecer pontos de contato por meio dos quais o ouvinte pode se certificar do seu senso da verdade, o filósofo assume para si a tarefa do poeta que, como afirma Kant, consiste na exposição da ideia estética ${ }^{17}$.

\section{Entre Kant e Cícero}

A ideia de que é função do homem superior e melhor, situado no plano do espírito, influenciar o homem inculto, situado no plano sensível, elevando-o, é devedora da Crítica do Juízo de Kant. Na introdução desta obra,Kant insistia na ideia de que existe uma influência do suprassensível no sensível, um dos objetivos da terceira Crítica consistindo na superação do abismo sistemático entre o conceito de natureza, estabelecido e fundamentado na Crítica da razão pura, e o de liberdade, estabelecido e fundamentado na Crítica da razão prática:

Ainda que na verdade subsista um abismo intransponível entre o domínio do conceito de natureza, enquanto sensível, e o do conceito de liberdade, como suprassensível, de tal modo que nenhuma passagem é possível do primeiro para o segundo (...), contudo este último deve ter uma influência sobre aquele... ${ }^{18}$.

Desenvolver e aprofundar essa influência do suprassensível no sensível tornase o objetivo central da Doutrina da ciência de Fichte. Em seu esforço de aperfeiçoar a filosofia de Kant, Fichte pretende atingir e demonstrar o princípio último dessa influência que, a rigor, só existe porque o suprassensível e o sensível provêm ambos de uma raiz comum ${ }^{19}$. A experiência da intuição intelectual a que a Doutrina da ciência conduz o leitor mostra em termos de uma evidência irrefutável essa raiz comum da ação e do pensamento. Ao fim e ao cabo, a Doutrina da ciência procura tornar evidente que o pensar é um agir pois está fundado inteiramente na liberdade da razão. A autoconsciência, nesse sentido, é o produto de uma ação livre do eu, que

17 Depois de ter mostrado, no $\$ 49$ da Crítica do Juízo, que o gênio busca apresentar (darstellen) uma Ideia da razão por meio da imaginação produtiva, Kant elenca os três modos possíveis de expressão ou comunicação da arte genial: o das artes elocutivas (eloquência e poesia), o das artes figurativas (arte plástica e pictórica), e o do jogo das sensações (música e arte das cores) (Cf. KANT, I. Crítica da Faculdade do Juízo. Tradução de António Marques e Valério Rohden Lisboa: Imprensa Nacional - Casa da Moeda, 1998, pp.227-31, B206-13). Enquanto Novalis, Schlegel e Hölderlin eram mais inclinados, na via das artes elocutivas, à poesia (e também à arte das cores), Fichte inclinavase mais à eloquência, tal como se pode ver nos Discursos à nação alemã (Redenan die Deutsche Nation), proferidos pelo filósofo em 1808 na Universidade de Berlim, nos quais se vê a relação íntima entre a Doutrina da Ciência e a linguagem (em especial com a língua alemã). Sobre isso, cf. PHILONENKO, A. L'oeuvre de Fichte, Paris: Vrin, 1984, pp.175-209.

18 KANT, I. Crítica da Faculdade do Juízo, 1998, p.57 (B XIX-XX).

19 Essa raiz comum, como se deduz da Grundlage, é a imaginação produtiva. Cf. FICHTE, J. G. A doutrina-da-ciência de 1794, 1988, pp.114-20. Compreender a filosofia de Kant segundo seu espírito, tal como deseja Fichte, significa compreender que a imaginação é capaz de unir o sensível e o inteligível porque ela é a origem de um e outro, na medida em que separa um do outro pela primeira vez. Sobre essa interpretação, cf. TORRES FILHO, R. R. O espírito e a letra: crítica da imaginação radical em Fichte. São Paulo: Ática, 1975, pp.76-124 
põe o eu ou como idêntico a si mesmo ou como diferente do outro, o não-eu. Na medida em que é inteiramente livre para se pôr ou não se pôr, o pensar torna-se ao mesmo tempo um agir: "teu pensar é para ti um agir"20escreve em 1797.

Ao pensar o dever do erudito [Gelehrter] a partir desses princípios demonstrados na Doutrina da ciência, Fichte concebe ser uma obrigação moral desse "homem superior e melhor"agir no mundo sensível. E fazê-lo, aqui, significa educar seus contemporâneos, ensinando-os que a moralidade consiste no esforço [Streben] de aproximação do sensível com o suprassensível, do eu empírico com o puro. Embora não se possa alcançar a adequação perfeita de ambos, pois então o eu se tornaria efetivamente absoluto, ou o próprio Deus, é dever de cada indivíduo esforçarse no sentido de submeter o eu empírico ao eu puro, numa aproximação infinita do primeiro ao segundo. Nesse sentido, é igualmente dever do erudito agir no mundo sensível, nesse caso é dever do erudito ensinar a buscar o estado de perfeição que caracteriza o bem supremo. Em suas preleções públicas, Fichte põe em prática esse imperativo, ao mostrar aos seus ouvintes que devem seguir seu sentimento e, por sua vez, fazerem o mesmo no futuro, quando tiverem finalmente se tornado homens superiores e melhores. Além de pôr em prática, nas preleções, algo que ele próprio, Fichte, considera um dever de sua categoria, é também o próprio conceito de ação recíproca [Wechselwirkung] que começa a atuar, isto é, a influência mútua dos indivíduos entre si em busca do aprimoramento universal da sociedade.

De modo a estabelecer uma concepção filosófica acerca dessa influência mútua dos indivíduos, bem como acerca da transmissão do saber do erudito ao nãoerudito, questão primordial das Preleções sobre o destino do erudito, e mostrar como é possível despertar o sentimento do ouvinte e confirmá-lo naquele que já o possui, Fichte se serve, nas preleções, de um modo embora velado, das investigações kantianas do gênio. 0 que está em jogo na concepção de Kant sobre o gênio, afinal, é a transmissibilidade de um certo tipo de conhecimento.Ao transpor a questão para o seu domínio próprio, Fichte procura pensar a transmissibilidade do conhecimento por meio da categoria do erudito em geral ${ }^{21}$. Assim como Kant com o gênio, também Fichte concebe que a comunicação do saber não pode ser guiada por regras determinantes; não pode ocorrer tal como no plano das disciplinas orientadas pelo princípio de imitação ou no das ciências em geral, nas quais se pode simplesmente imitar os passos indicados pelo autor para chegar aos mesmos resultados. Fichte, nesse sentido, observa a distinção kantiana entre gênio e cientista (ao contrário deste, o

20 FICHTE, J. G. O princípio da Doutrina-da-ciência, 1988, p.179.

21 Essa aproximação do gênio com o erudito, apenas indicada nessas preleções de 1794, será mais amplamente realizada nas preleções Sobre a essência do Erudito (Über das Wesendes Gelehrten), ministradas por Fichte em 1805 na Universidade de Erlangen. Cf. para isso SCHMIDT, J. Die Geschichte des Genie-Gedankens in der deutschen Literatur, Philosophie und Politik 1750-1945. Darmstadt: Wissenschafltiche Buchgesellschaft, 1985, vol. I, pp.385-89. 
gênio não pode explicar de onde provêm suas ideias), de modo que a transmissão ou comunicação do saber deve apenas ocasionar a livre associação das faculdades criadoras, e jamais determinar o modo como ele deve receber as informações. A ligação das faculdades com o objeto é sempre apenas ocasional, e nunca necessária, como no caso daquele que o imita. "Qualquer um concorda que o gênio se opõe totalmente ao espírito de imitação" 22, afirma Kant, o que significa que a transmissão de seu saber não pode ser determinada por nenhuma regra, mas que a sua produção deve trazer em si uma simples indicação capaz de suscitar a livre associação das faculdades de quem a recebe. É nesse sentido que o próprio gênio não pode explicar como as suas ideias "surgem e [se] reúnem na sua cabeça, porque ele mesmo não o sabe e, portanto, também não o pode ensinar a nenhum outro". Somente pela criação de uma obra vivificadora, uma obra de espírito,o gênio é capaz de despertar outro gênio a fazer um uso livre de suas faculdades, de modo que sua obra deve constituir "um exemplo não para a imitação (...), mas para a sucessão por um outro gênio, que por este meio é despertado para o sentimento da sua própria originalidade"23.

Salvo algumas raras exceções, Fichte não usa o termo gênio. Mas, como se disse,é possível traçar um paralelo entre a concepção do erudito de Fichte e o gênio de Kant. Em ambos os casos, o objetivo consiste em mostrar como é possível a transmissão de uma "representação da imaginação que dá muito o que pensar, sem que contudo qualquer pensamento determinado, isto é, conceito, possa ser-lhe adequado" 24 . Em ambos os casos, trata-se de saber como expressar uma ideia sem determinar o modo como o ouvinte deve recebê-la, despertando o uso livre das faculdades do leitor, ouvinte ou espectador. Como afirma Kant, trata-se, em última análise, de mostrar essa

feliz relação, que nenhuma ciência pode ensinar e nenhuma diligência pode aprender, de encontrar ideias para um conceito dado e por outro lado de encontrar para elas a expressão pela qual a disposição subjetiva do ânimo daí resultante (...) pode ser comunicada a outros ${ }^{25}$.

Tanto o gênio em Kant como o erudito em Fichte procuram estabelecer esse duplo movimento: encontrar ideias para um conceito dado e, ao mesmo tempo, um modo de expressão capaz de comunicar a disposição subjetiva do ânimo que resulta daquela conformidade a fins. Na segunda preleção sobre $O$ destino do erudito, após mostrar que a destinação do homem consiste na vida em sociedade, que há no homem um impulso social - "se vive isolado, não é um homem inteiro, completo, e contradiz-

22 KANT, I. Crítica da Faculdade do Juízo, 1998, p.212 (B 183).

23 Idem, p.224 (B 200), grifo meu.

24 Idem, p.219 (B 192), grifo meu.

25 Idem, p.223 (B 198), grifo meu. 
se a si mesmo"26 -, Fichte tira disso a consequência mais imediata. Segundo se lê na terceira preleção, se o homem está destinado a viver em sociedade, então é possível afirmar que há nele um

impulso para a comunicação, isto é, o impulso para cultivar [ausbilden] alguém sob aqueles aspectos em que nós somos particularmente cultivados, o impulso para tornar, tanto quanto possível, cada um dos outros igual a nós mesmos, ao que somos de melhor ${ }^{27}$.

Assim como uma das principais características do gênio em Kant é a livre comunicação do seu saber, também o erudito de Fichte será definido por esse elemento. Mas, como se deseja mostrar a seguir, as raízes da figura do erudito a que se refere Fichte nas suas preleções não estão apenas no gênio da Crítica do Juízo de Kant, mas também em Cícero, para quem constituía um dever do filósofo cultivar, ao lado das qualidades propriamente filosóficas, também as da oratória e da eloquência, de modo a garantir justamente a comunicação do saber acumulado na vida erudita.

Para entender como a teoria do erudito de Fichte é devedora de Cícero, é preciso antes de tudo compreender que as cinco preleções sobre o destino do erudito ministradas no início do verão de 1794 constituem apenas uma parte do ciclo de preleções anunciadas naquele ano, no Catalogus praelectionum ${ }^{28}$ da Universidade de lena, sob o título geral De officiis eruditorium (Dos deveres dos eruditos). Segundo o plano geral deste ciclo, as cinco preleções ministradas no verão de 1794 (Preleções sobre o destino do erudito) receberiam uma continuação no inverno de 1794/5. Ao contrário daquelas, estas últimas, porém, não foram impressas e publicadas, tendo restado apenas os esboços e as anotações do filósofo ${ }^{29}$. A relação com Cícero, entretanto, surge já no título das conferências de Fichte, De officiis eruditorium, uma referência clara ao De officiis (Dos deveres) do orador latino.

No De officiis, com efeito, Cícero define como tarefa do filósofo o ensino dos deveres da virtude aos seus descendentes: “quem poderá ousar chamar-se filósofo sem nunca ter ministrado preceitos alguns sobre os deveres?"30. Para tanto, segundo Cícero, o filósofo deve unir às suas qualidades propriamente filosóficas também as

26 FICHTE, J. G. O Destino do Erudito, 2014, p.38.

27 Idem, p. 51.

28 As preleções de verão de 1794 são apresentadas no catálogo como "Publice locum de officiis eruditorum exponet" e as preleções de inverno como: "Publice die atque hora adhuc indicanda de officiis eruditorum disserere perget", ao que acrescentava uma nota em alemão: "o senhor professor Fichte continuará suas preleções sobre os deveres do erudito". apud LAUTH, R. In: FICHTE, J. G. Von den Pflichten der Gelehrten. Hamburg: Felix Meiner Verlag, 1971, p.XIX.

29 Essas preleções foram traduzidas em FICHTE, J. G. Sobre o espírito e a letra na filosofia, 2015, pp.237-340. Um quadro geral de todo esse ciclo de preleções sobre os deveres do erudito foi estabelecido por Reinhardt Lauth (In: FICHTE, J. G. Von den Pflichten der Gelehrten, 1971, pp.XXVI-XXVII) e reproduzido por Ricardo Barbosa no Posfácio a FICHTE, J. G. O destino do erudito, 2014, pp.110-11.

30 CÍCERO, M. T. Dos deveres, 2000, p.16. 
eloquentes, cultivando ambas ao mesmo tempo no sentido de realizar a tarefa de educar seu povo. Esta teria sido, segundo Cícero, a grande falha dos pensadores gregos:

Em todo caso, penso que Platão, se quisesse cultivar a oratória forense, poderia ter falado com grande gravidade e abundância, e Demóstenes, se tivesse retido aquilo que aprendera com Platão e acerca disso desejasse falar, poderia tê-lo feito com elegância e esplendor; o mesmo penso acerca de Aristóteles e de Isócrates - cada um deles, deleitado pelo estudo de um gênero, desprezou o outro ${ }^{31}$.

O traço característico do pensamento romano em relação ao grego, assim, é a tentativa de unificação da filosofia com a oratória, o pensador ideal sendo aquele capaz de cultivar essas duas virtudes ao mesmo tempo. 0 dever do erudito, que o próprio Cícero assume para si, consiste na difícil tarefa de mostrar ao povo romano que o futuro da nova civilização não estava na demonstração de superioridade da língua latina (e da oratória) em detrimento da grega (e da filosofia) ou vice-versa, como parecia acontecer naquele momento entre os eruditos latinos. Invocando o discurso da temperança, pelo contrário, Cícero procura ensinar aos seus concidadãos que a virtude consiste justamente na conciliação de uma coisa com a outra, o grego com o latim e a filosofia com a oratória. Num certo sentido, como educador e erudito,Cícero assume para si a tarefa de zelar para que a passagem do grego para o latim ocorresse de modo que a cultura romana nascente pudesse conservar, junto com "a força das palavras" de sua natureza oratória, a riqueza de pensamento da filosofia grega. Para ele, a grandeza de Roma estaria salva se os seus eruditos e seu povo soubessem exercitar ao mesmo tempo o grego e o latim, a filosofia e a oratória.

Cícero inicia o Do sumo bem e do sumo mal pelo mesmo tema, mencionando logo no começo a dificuldade em que se encontra de ter de agradar ao mesmo tempo aos que vituperam a filosofia e aos que desprezam os escritos latinos. Por um lado, escreve, há os que, "instruídos nas letras gregas e depreciadores das latinas (...), julgarão preferível ocupar o tempo com ler os gregos" ${ }^{32}$, declarando-se "tão inimigos do povo romano que possam desprezar ou rejeitar a Medeia de Ênio ou a Antíope de Pacúvio"33. Por outro, há os que desprezam inteiramente os gregos e "reprovam todo e qualquer tipo de filosofia" ${ }^{34}$. Declarando-se perplexo com uma época a tal ponto dilacerada, Cícero lamenta não existirem mais eruditos tais como "Perseu, e sobretudo aquele Cipião, e aquele Rutílio cujo julgamento era tão acurado, que Ihe permitia dizer que escrevia tanto para os tarentinos como para os consentinos

\section{Idem, ibidem.}

32 CíCERO, M. T. Do sumo bem e do sumo mal. Tradução de Carlos Ancêde Nougué. São Paulo: Martins Fontes, 2005, p.1.

33 Idem, p.3 (tradução levemente modificada).

34 Idem, p.1. 
e os sicilianos" 35 . Com efeito, os verdadeiros eruditos, capazes de falar a todos incondicionalmente, sejam amantes do grego e da filosofia, sejam amantes do latim e da oratória, faziam parte de uma espécie em extinção.

A principal carência do erudito romano, para Cícero, consistia na sua incapacidade de enxergar o grego para além do grego e o latim para além do latim, que Fichte denomina, nas preleções Sobre os deveres dos eruditos, de geistloser Buchstäbler, isto é, “aqueles que se prendem ao pé da letra”.Essa característica pode ser vista na crítica de Cícero, principalmente no caso dos que "dizem desprezar todos os escritos latinos", mais difícil de serem satisfeitos, pois, embora os escritos latinos não os agradem, eles "leem não com desgosto as fábulas latinas - traduzidas do grego ao pé da letra" 36 . A dificuldade de agradar a estes últimos, segundo Cícero, reside no fato de que essas fábulas latinas os apetecem somente por terem sido traduzidas do grego ao pé da letra, sendo, segundo o espírito, mais gregas do que latinas. Demasiado presos à letra, os eruditos latinos, nesse sentido, não eram capazes de ir além dela, de ler Platão em latim ou a tradução latina da Electra de Sófocles feita por Ênio. A tarefa a que se propõe Cícero, assim, é bastante clara: é preciso educar os descendentes no sentido de torná-los verdadeiros eruditos, o que significa tornálos capazes de pensar o grego para além da letra grega e o latim para além da letra latina. Isso, entretanto, só é possível ao filósofo que estudar oratória e ao orador que estudar filosofia, ao grego que estudar latim e ao latino que estudar o grego:

E eu, que nos trabalhos e perigos forenses não creio jamais ter abandonado o posto em que me colocou o povo romano, devo trabalhar quanto possa para que com o meu estudo e diligência se tornem mais doutos os meus concidadãos, e não disputar com os que preferem ler em grego (se é que o fazem verdadeiramente e não o fingem), e servir os que querem valer-se das letras tanto em grego como em latim... ${ }^{37}$.

Nesse mesmo sentido da crítica de Cícero aos eruditos literais de Roma,Fichte, nas preleções sobre $O$ espírito e a letra na filosofia, afirma que sua época “manifesta uma decidida propensão à falta de espírito [Geistlosigkeit]" ${ }^{38}$, dominada que é pelos geistloser Buchstäbler, filósofos e eruditos que, carentes de espírito, não conseguem ir além da simples letra. Na primeira dessas preleções do inverno de 1794/5, Fichte descreve essa carência de espírito como uma incapacidade que, embora estivesse sempre presente entre os homens, nunca esteve presente "num grau tão elevado e em uma extensão tão ampla como em nossa época enlanguescida e entre nossas nações debilitadas pela escravidão, pelo luxo e pela soberba"39. Faz-se, por isso, necessária

35 Idem, pp.4-5.

36 Idem, p.3.

37 Idem, p.6 (grifo meu).

38 FICHTE, J. G. Sobre o espírito e a letra na filosofia, 2015, p.241.

39 Idem, p.248. 
uma educação da classe erudita, uma educação que, baseada na distinção filosófica entre o espírito e a letra, permita ao filósofo e ao erudito tomar consciência de sua tarefa, bem como do estado atual em que se encontra sua cultura. 0 erudito, como afirma Fichte, "é, conforme a sua destinação, o mestre [Lehrer] da humanidade", aquele que "não vê apenas o presente, mas também vê o futuro", que "não considera apenas o ponto de vista atual, mas considera também para onde o gênero humano tem de caminhar de agora em diante, se deve permanecer no caminho de sua meta última e não se desviar dele ou retroceder". "A esse respeito", completa, "o erudito é o educador da humanidade" 40 .

Assim como coube a Cícero essa não pequena tarefa, é Fichte quem a assumirá no final do século XVIII na Alemanha, motivo pelo qual o filósofo, seguindo os preceitos do pensador latino, procurará em suas preleções conjugar a filosofia com a arte de falar bem.

\section{O espírito e a letra ou a filosofia e a oratória}

A primeira pergunta que Fichte procura responder nas preleções de inverno, continuando as preleções ministradas no último verão, é a que se refere ao espírito. Que é, afinal, espírito? A resposta evidencia mais uma vez a íntima relação do erudito de Fichte com o gênio da Crítica do Juízo de Kant, para o qual espírito, resultante de um jogo da imaginação produtiva com as faculdades superiores,é "o princípio vivificante no ânimo"41. Como se lê em uma passagem lapidar da segunda dessas preleções do inverno de 1794/5 de Fichte, intitulada Eu quero investigar em que se diferencia em geral o espírito da letra na filosofia, também para ele o espírito resulta da imaginação produtiva, como já afirmava Kant. Em Fichte, entretanto, a imaginação, ao criar uma obra de espírito e assim influenciar livremente a atividade alheia, é responsável por operar uma transformação que, no fim, resultará na formação da própria consciência de si:

A faculdade dessa transformação é a imaginação. Ela é formadora [Bildnerin]. Eu não falo dela enquanto provoca, liga ou ordena novamente representações já ocorridas anteriormente, mas enquanto torna algo representável em geral pela primeira vez. Nessa medida, ela é criadora, criadora de uma consciência. Nesta função, não se é consciente dela, precisamente porque antes dessa função não há nenhuma consciência. A imaginação criadora. Ela é o espírito ${ }^{42}$.

A imaginação é espírito na medida em que, considerada em sua natureza produtiva, e não reprodutiva ${ }^{43}$, é capaz de criar algo espiritual a partir da matéria

40 FICHTE, J. G. O destino do erudito, 2014, pp.74-5 (tradução levemente modificada).

41 KANT, I. Crítica da Faculdade do Juízo, 1998, p.218 (B 192).

42 FICHTE, J. G. Sobre o espírito e a letra na filosofia, 2015, p.313.

43 A distinção para Fichte entre imaginação produtiva e reprodutiva reside na concepção de que esta última se contenta com a simples imitação de algo preexistente, precisamente o que faz com que 
sensível dada pela natureza. Como afirma Kant, "enquanto faculdade de conhecimento produtiva”, a imaginação "é mesmo muito poderosa na criação como que de uma outra natureza a partir da matéria que a natureza efetiva lhe dá"44. Ora, essa matéria que a natureza efetiva the fornece e a partir da qual ela cria outra natureza, de caráter espiritual, é, segundo outra preleção de Fichte do mesmo período, o próprio sentimento:

Aquilo que a imaginação forma e a consciência mantém reside no sentimento. 0 sentimento, que aqui não posso nem devo esclarecer, é a matéria de tudo o que é representado e o espírito em geral ou a imaginação produtiva podem ser descritos como a faculdade de elevar sentimentos à consciência. (...) Quanto mais rápida e ativamente a imaginação de um homem eleva seus sentimentos à representação; quanto mais fortemente por esse mesmo motivo as representações colidirem com representações em seu espírito, tanto mais rico de espírito é o homem; quanto mais vagarosamente compreende e apreende e quanto mais languidamente se desfaz o fio de sua consciência, tanto menos espírito possui ${ }^{45}$.

Como espírito é a faculdade de elevar sentimentos à clara consciência e essa faculdade é a imaginação criadora, a educação dos que se atêm ao pé da letra deve iniciar com um apelo à imaginação criadora individual. Na Grundlage, Fichte chama esse apelo de um travo [Anstoss] que a atividade infinita do eu recebe do não-eu, de modo que ela possa refletir essa atividade sobre si mesma, tornando possível a consciência de $\mathrm{si}^{46}$. Esse apelo, esse travo proveniente do não-eu, que desperta a imaginação produtiva do geistloser Buchstäbler e torna-lhe possível sair do movimento de inércia infinito de sua atividade pura, pode ser fornecido de múltiplas formas, por exemplo, por meio da $a r t e^{47}$. Nas suas preleções sobre os deveres do erudito, entretanto, Fichte procura fazê-lo unindo ao pensamento filosófico a arte oratória, à maneira de Cícero, isto é, um discurso que, capaz de sair da região abstrata do

seu produto seja geistlos, sem espírito. Carente de imaginação criadora, o filósofo geistlos, assim, não filosofa verdadeiramente, mas apenas "repete meras regras de como se deveria filosofar". No domínio da criação, pelo contrário, a imaginação não simplesmente imita algo exterior a ela, mas põe na coisa algo que já está de alguma maneira no próprio eu. Esse algo, que o eu tem em si mesmo e que é formado pela imaginação são os sentimentos, não os referentes à vida animal do homem, mas os sentimentos referentes às leis da ética, da harmonia espiritual e da "unificação de todos em um reino da verdade e da virtude". "Estes sentimentos - se me permitem me expressar assim - residem numa região mais profunda de nosso espírito, em seu mais secreto santuário" (FICHTE, J. G. Sobre o espírito e a letra na filosofia, 2015, p.245).

44 KANT, I. Crítica da Faculdade do Juízo, 1998, p.219 (B 193).

45 FICHTE, J. G. Sobre o espírito e a letra na filosofia, 2015, p.243.

46 "Sobre a atividade de que o eu vai ao infinito, na qual, justamente porque ela vai ao infinito, nada pode ser distinguido, ocorre um travo; e a atividade, que de nenhum modo pode ser anulada com isso, é refletida, impelida para dentro; adquire a direção diretamente oposta" (FICHTE, J. G. Doutrina-da-ciência de 1794, 1988, p.121).

47 Fichte procura mostrar o papel da arte e do artista nessa mesma tarefa de vivificação do espírito no manuscrito Sobre o espírito e a letra na filosofia - Numa série de cartas. Escrito a partir do material dessas preleções do inverno de 1794/5, esse manuscrito acabou sendo o móbile da chamada disputa das Horas com Schiller, que recusou publicá-lo em sua revista As Horas. 0 manuscrito, por isso, foi publicado apenas em 1798, no Philosophisches Journal, editado por Immanuel Niethammer. 
espírito e de transmutar-se em corpo,adquire um sentido para aquele que, imerso na inércia do sensível, desconhece o mundo do espírito ou possui um sentimento vago e obscuro acerca dele.Ao unificar a filosofia com a capacidade de falar do orador, Fichte busca atingir o nobre sentimento do ouvinte vivificando a atividade de sua imaginação, despertando-a de um modo que ela possa por si mesma elevar esse sentimento ainda obscuro à clara consciência de si. Por isso, nas preleções sobre 0 destino do erudito, Fichte reafirma a necessidade da contraimagem, do travo, que não pode vir de outro lugar a não ser da relação com o outro, daquilo que o filósofo chama de não-eu: "a todos os conceitos que se encontram no seu Eu deve ser dada uma expressão, uma contraimagem [Gegenbild] no Não-eu"48. Pois é unicamente a partir dessa relação com o outro, com o oposto ao eu, que os conceitos situados no Eu adquirem pela primeira vez um conteúdo racional. O destino, o chamado ou a vocação do erudito, dependendo do modo como se traduz o termo Bestimmung ${ }^{49}$, deve ecoar sensivelmente nas palavras pronunciadas pelo outro e somente então adquire um sentido. "Para nós", escreve Fichte afinal, "tudo ocorre no mundo físico, inclusive as ideias espirituais de seres sensíveis", de modo que "o espírito livre é vestido com um corpo" 50 .

Como se lê na primeira preleção do inverno de 1794/5, intitulada Sobre o espírito e o corpo em geral, Fichte fala dessa transmutação da ideia em palavras em termos de uma “centelha” que o orador lança na plateia buscando inflamá-la: "não importa de onde - de algum lugar invisível para os senhores e para todo olho mortal cai uma centelha que vos toma violentamente e vos conduz àquela profundeza cheia de segredos" ${ }^{51}$. Nessa mesma preleção, perto de seu encerramento, Fichte revela ter sido exatamente este o desejo perseguido ao longo de toda sua fala: "o desejo de que, embora escondido aos meus olhos, habite nos senhores muito espírito e que, de tempos em tempos, eu possa contribuir em algo para isso, lançando em suas almas fagulhas capazes de despertá-las e de atiçá-las poderosamente"52.Isso, portanto, é suficiente para mostrar que a tarefa assumida pelo filósofo nessas preleções consiste em atiçar o público, lançando fagulhas ou centelhas que nada são senão ideias transformadas em corpos, isto é, palavras:

48 FICHTE, J. G. O Destino do Erudito, 2014, p.36, grifo meu.

49 De acordo com este contexto, seria possível também traduzir Bestimmung por vocação, na medida em que pode ser entendido como o chamado da voz [Stimme] interior do erudito, guardando assim também no português o jogo de palavras entre vocação e voz, Bestimmung e Stimme.

50 FICHTE, J. G. Sobre o espírito e a letra na filosofia, 2015, p.249.

51 Idem, p.245.

52 Idem, p.259. É a essa centelha na forma da palavra escrita que aludiria Kant na famosa passagem dos Prolegômenos em que afirma ter sido Hume quem o despertou de seu sono dogmático. $\mathrm{Na}$ passagem, Kant usa o termo "a primeira centelha dessa luz". Cf. para isso SUZUKI, M., O gênio romântico. Crítica e história da filosofia em Friedrich Schlegel. São Paulo: Iluminuras/Fapesp, 1998, p.43 e ss. 
Eu próprio me encontro nesta situação neste e em qualquer momento diante dos senhores. Ofereço-lhes um produto, ao qual creio ter infundido algumas ideias. Mas eu não lhes dou as próprias ideias, pois estas eu não posso dar. Eu dou aos senhores o simples corpo e minhas palavras, que os senhores ouvem, são estes $\operatorname{corpos}^{53}$.

Mas não é qualquer palavra que pode atingir esse fim. A palavra, essa corporificação do espírito, se deve funcionar como centelha, precisa ser trabalhada e arranjada de um modo que atinja os nobres sentimentos do ouvinte. Como se disse ao início deste artigo, faz-se necessário um texto disposto e pontuado visando antes a declamação do que propriamente a sintática e a lógica, capaz de despertar a faculdade da imaginação e que obedeça àquele preceito segundo o qual "os espíritos são livres e não podem ser determinados, mas devem determinar-se a si mesmos, por meio da indicação de algum fenômeno no mundo sensível" ${ }^{54}$. No fim, este é o objetivo da boa poesia, dos bons livros e dos bons discursos, cada um expondo a seu modo uma ideia, um estado de ânimo, buscando vivificar os espíritos e evitar que "todo o impresso deva se deixar usar como um livro de receitas, um livro de aritmética ou um regulamento de serviço" 55 .

Ao ler suas preleções sobre $O$ destino do erudito para o público da universidade de lena, portanto, Fichte encarna o erudito de que fala, cuja tarefa é influenciar os indivíduos e a sociedade como um todo em vistas de um ideal de perfeição. 0 destino do homem em geral, como afirma na segunda preleção de $O$ destino do erudito, é viver em sociedade, isto é, numa "comunidade conforme a fins". Nessa sociedade, cada indivíduo deve contribuir para o desenvolvimento e o progresso do gênero, agindo, procurando instituir no mundo da efetividade o mundo da liberdade absoluta e plena. Ao agir, os indivíduos se influenciam mutuamente, o que é suficiente para deduzir o conceito de ação recíproca [Wechselwirkung], por meio da qual a sociedade busca o aperfeiçoamento da espécie num progresso infinito.

Mas o primeiro passo nessa direção é compreender que as noções de ação recíproca e de aperfeiçoamento infinito dependem primeiramente da ação individual. Se os indivíduos não despertarem de algum modo para a ação, não haverá reciprocidade, aperfeiçoamento infinito e tampouco o mundo ético do espírito. Tanto as preleções de verão de 1794 como as de inverno sobre os deveres do erudito, assim, contêm passagens incitativas e exortatórias, de um filósofo que, à maneira de um Demóstenes diante do povo ateniense,recorre aos sentimentos dos alemães, tal como se pode ver no final da já citada quinta preleção sobre o Destino do Erudito, por exemplo, em que Fichte revela o fim último de sua filosofia: “Agir! Agir! É para

53 FICHTE, J. G. Sobre o espírito e a letra na filosofia, 2015, p.251.

54 Idem, p.249.

55 FICHTE, J. G. O Destino do Erudito, 2014, p.12. 
isso que estamos aqui" ${ }^{66}$, exorta, mostrando que sua filosofia não é um simples pensamento sobre as coisas, que não se trata de mais um sistema de erudição vazia, mas de uma filosofia para a qual a erudição, a sabedoria e a doutrina [die Lehre] devem estar de algum modo a serviço da transformação do mundo e da sociedade. É o próprio Fichte quem o afirma numa carta de 2 de março de 1790 à sua futura esposa:

Eu mesmo não levo o menor jeito de um erudito de métier. Não desejo simplesmente pensar; meu desejo é agir. (...) Tenho apenas uma paixão, apenas um desejo (...): o de atuar ao meu redor. Quanto mais ajo, mais feliz me sinto em relação a mim mesmo ${ }^{57}$.

\section{Referências}

CÍCERO, M. T. Dos deveres (De officiis). Tradução de Carlos Humberto Gomes. Lisboa: Edições 70, 2000.

Do sumo bem e do sumo mal. Tradução de Carlos Ancêde Nougué. São Paulo: Martins Fontes, 2005.

FICHTE, J. G. A doutrina-da-ciência de 1794. Tradução de Rubens Rodrigues Torres Filho. São Paulo: Abril Editorial, 1988.

Fichte im Gespräch. Stuttgart - Bad Cannstatt: Friedrich Frommann Verlag (Günther Holzbog), 1981, vol.I.

O conceito da doutrina-da-ciência. Tradução de Rubens Rodrigues Torres Filho. São Paulo: Abril Editorial 1988.

Hedra, 2014.

O destino do erudito. Tradução de Ricardo Barbosa. São Paulo: Editora

- O programa da doutrina-da-ciência. Tradução de Rubens Rodrigues Torres Filho. São Paulo: Abril Editorial 1988.

Sobre o espírito e a letra na filosofia. Tradução de Ulisses Razzante

Vaccari. São Paulo: Humanitas/Imprensa Oficial do Estado de São Paulo, 2015. Von den Pflichten der Gelehrten. Hamburg: Felix MeinerVerlag, 1971.

HEGEL, G.W.F. Briefe von und an Hegel. HOFFMEISTER, J.(org.). Hamburg: Felix Meiner Verlag, 1952.

KANT, I. Crítica da Faculdade do Juízo. Tradução de António Marques e Valério Rohden. Lisboa: Imprensa Nacional - Casa da Moeda, 1998.

PHILONENKO, A. L'oeuvre de Fichte. Paris: Vrin, 1984.

ROSALES, J. R. "Limite e realidade. Os primeiros passos no Sistema do idealismo transcendental”. In: REY PUENTE, F. e ALVES VIEIRA, L. (orgs.) As filosofias de Schelling. Belo Horizonte: Editora UFMG, 2005, pp.113-52.

SCHMIDT, J.Die Geschichtedes Genie-Gedankensinder deutschenLiteratur, Philosophie und Politik 1750-1945. Darmstadt: Wissenschafltiche Buchgesellschaft, 1985.

56 Idem, p.92.

57 Apud Barbosa, idem, p.95. 
SUZUKI, M.O gênio romântico. Crítica e história da filosofia em Friedrich Schlegel. São Paulo: Iluminuras/Fapesp, 1998.

TORRES FILHO, R. R. O espírito e a letra: crítica da imaginação radical em Fichte. São Paulo: Ática, 1975.

Recebido em: 10.03.2015

Aceito em: 06.11.2015 